\title{
THE ELEVATION OF OSTEOBLAST ACTIVITY IN RAT BONE MARROW MESENCHYMAL STEM CELLS IN OSTEOGENIC MEDIUM EXPOSED WITH MELATONIN IN PHYSIOLOGICAL DOSES
}

\author{
Nurma Yuliyanasari ${ }^{1}$, Gondo Mastutik ${ }^{2}$, Suhartono Taat Putra $^{2}$ \\ ${ }^{1}$ Students of the Master Program, Basic Medical Science, Faculty of Medicine, Airlangga University \\ ${ }^{2}$ Department of Anatomic Pathology, Faculty of Medicine, Airlangga University
}

\begin{abstract}
ABSTRAK
Tujuan dari penelitian ini adalah untuk membuktikan peningkatan aktivitas osteoblas pada biakan rat bone marrow mesenchymal stem cells (BM-MSCs) di medium osteogenik yang dipapar melatonin dosis fisiologis melalui pemeriksaan kadar alkaline phosphatase (ALP) dan osteocalcin. Penelitian ini menggunakan rat BM-MSC tulang femur Rattus Norvegiccus sebagai sampel. Rat BM-MSCs tersebut dibiakkan di medium $\alpha-M e m$, didiferensiasikan dalam medium osteogenik dan diberi melatonin selama 21 hari. Penelitian ini dibagi menjadi empat kelompok yaitu kelompok KO (melatonin OnM), K1 (melatonin 25nM), K2 (melatonin 50nM), dan K3 (melatonin 100nM). Rat BM-MSCs dikarakterisasi menggunakan marker CD45-dan CD 105+ dengan teknik imunositokimia, diwarnai dengan Alizarin red pada hari ke-15. Kadar ALP dan osteocalcin diperiksa pada hari ke-21 dengan menggunakan teknik ELISA. Hasil penelitian ini menunjukan bahwa tidak terdapat perbedaan kadar ALP antar kelompok perlakuan dan terdapat perbedaan kadar osteocalcin antar kelompok, yaitu antara kelompok KO dengan kelompok K1, K2, K3, serta kelompok paparan melatonin K1 dan K2. Kesimpulan penelitian ini adalah terdapat peningkatan aktivitas osteoblas pada biakan rat BM-MSCs di medium osteogenik yang dipapar melatonin dosis fisiologis yang ditandai dengan peningakatan kadar osteocalcin. (FMI 2017;53:41-48)
\end{abstract}

Kata kunci: melatonin, BM-MSCs, kadar ALP, kadar osteocalcin, aktivitas osteoblas

\begin{abstract}
The objective of this study was to analyze the elevation of osteoblast activity in bone marrow mesenchymal stem cells (BM-MSCs) in osteogenic medium by physiological doses of melatonin administration by measuring alkaline phosphatase (ALP) and osteocalcin level.This studyused BM-MSCs from Rattusnorvegiccus femur bone. Rat BM-MSCs were cultured in $\alpha$-Mem medium, differentiated in osteogenic medium, and administrated melatonin up to 21 days. This study was divided into 4 groups, KO (control group), K1 (administrated of $25 \mathrm{nM}$ melatonin), K2 (administrated of $50 \mathrm{nM}$ melatonin), and K3 (administrated of $100 \mathrm{nM} \mathrm{melatonin).} \mathrm{Rat} \mathrm{BM-}$ MSCs were characterized CD 45- and CD 105+ marker using imunocytochemistry analysis and stained with Alizarin red after 15 days treatment. ALP and osteocalcin level were measured using ELISA Kit in days 21st.There weren't differences ofALP level beetwen groups and there are differences ofosteocalcin level between control groups (KO) withK1, K2, dan K3, and beetwen K1 and K2. The conclusion of this study was that there were an elevation of osteoblast activity in rat BM-MSCs in osteogenic medium by physiological doses of melatonin administration characterized by the elevation of osteocalcin level. (FMI 2017;53:41-48)
\end{abstract}

Keywords: melatonin, BM-MSCs, ALP level, osteocalcin level, osteoblast activity

Correspondence: Gondo Mastutik, Department of Anatomic Pathology, Faculty of Medicine, Universitas Airlangga, J1. Prof DrMoestopo 47, Surabaya 60131, phone. 62-31-5020251, ext 151, e-mail: gondomastutik@gmail.com

\section{INTRODUCTION}

Increased osteoblast activity was found in cultured bone marrow mesenchymal stem cells (BM-MSCs) in osteogenic medium exposed with melatonin in physiological dosage. A previous study reported that administration of melatonin can increase the activity of osteoblasts by increasing the osteogenic differentiation of BM-MSCs (Radio et al. 2006; Sethiet al. 2010). ALP and osteocalcin are the major protein used as marker of osteoblasts activity in the process of osteogenesis(Patti 2013 ).The study of this was limited to the examination of genes and have not yet reached the level of protein and thus the activity of osteoblasts found in cultured BMMSCs in medium osteogenic exposed with melatonin in physiological dosage remains unclear.

Melatonin is an indolamin hormone generated primarily by the pineal gland and plays a role in various physiological processes including bone remodeling. Melatonin has the ability to increase bone formation as well as to decrease bone resorption. The decrease level melatonin ini human could inhibit osteoblast activity so that the process of bone formation is disturbed, as in 
case of osteoporosis. Osteoporosis is a bone-related disease that has high incidence, mortality, and morbidity. More than 200 million women worldwide are known to suffer from osteoporosis at the age of 60 years (Maria \&Enderby 2014). The number is increasing due to complications such as fractures suffered (Riggs et al. 1995; National Osteoporosis Foundation 2014).

Decrease level of melatonin in human is thought to be one of the causes of osteoporosis, while the administration of melatonin was suggested that can increase bone formation and capable of reducing osteoporosis. Study conducted by Feskanich et al. (2008) states that low melatonin levels in more than 38,000 postmenopausal women who worked at night for more than 20 years significantly contribute to osteoporosis and the risk of suffering fractures in forearm and pelvis. Meanwhile, administration of melatonin is known to improve the mechanism of bone remodeling in BMMSCs (Radio et al. 2006; Sethi et al. 2010). Thus, this study was conducted to explain the elevation of osteoblast activity found in cultured BM-MSCs in the medium of osteogenic exposed with melatonin in physiological dosage, so it can be used as a scientific base to develop therapies for diseases that require increased osteoblast activity, such as osteoporosis.

\section{MATERIALS AND METHODS}

\section{Isolation and culture of Bone Marrow Mesenchymal Stem Cells}

BM-MSCs were being isolated from the femur bone of 1 adult male rat from Wistar strain (Rattusnorvegiccus) aged 6-8 weeks. The rat was sacrificed by ketamine (22$44 \mathrm{mg} / \mathrm{kg}$ ) and diazepam (3-5 mg/ kg) intra muscular. The bone was being isolated and then being washed with saline water and then being placed inside the conical tube containing $\alpha$-MEM medium (Sigma, USA) and antibiotics (100 units/ $\mathrm{ml}$ penicillin $\mathrm{G}$ and $100 \mu \mathrm{g} /$ $\mathrm{ml}$ streptomycin). Cells were being transferred to the laboratory and being washed again with PBS (Sigma, USA, and $\alpha$-MEM). Femur bone was being cut into pieces while the bone marrow was washed with $3 \mathrm{ml}$ of $\alpha$-MEM medium. The cells were then being transferred into 3 pieces of conical tube (Corning, China) and $3 \mathrm{ml}$ of FicollHistopaque (Sigma, USA) was being added slowly. The cells then centrifuged at $1600 \mathrm{rpm}$ for 30 minutes. Buffy coat obtained between FicollHistopaque and the medium was taken and added to the $\alpha$-MEM medium. Samples were being centrifuged again with the speed of $1600 \mathrm{rpm}$ for 5 minutes, and the pellet results from centrifugation was being transferred into $5 \mathrm{~cm}$ of petridish contained $\alpha$-MEM medium. The samples were then being incubated at $37^{\circ} \mathrm{C}$ containing $5 \% \mathrm{CO} 2$ so that the adjacent cells can be sticking together.

\section{Cell culture and expansion}

MSCs that have been isolated were then being cultured for up to 2 pieces of petridish (Corning, China) with 10 $\mathrm{cm}$ in diameter (5x passages) using $90 \%$ confluent. Cells were incubated at $37^{\circ} \mathrm{C}$ containing $5 \%$ of $\mathrm{CO} 2$, and the medium was being replaced for every 3 or 4 days. Each cell reached $90 \%$ confluent, cells were subcultured (passage) using $1.5 \mathrm{cc}$ of trypsin (Sigma, USA).

\section{Characterization of BM-MSCs}

BM-MSCs were made into a single cell with trypsinization then being fixed with acetone at $-20^{\circ} \mathrm{C}$ for 10 minutes. Samples were blocked with $1 \%$ fetal calf serum (FCS) (Sigma, USA), and primary antibody was add. Samples were incubated for 45 minutes up to 1 hour. Samples were washed with PBS and secondary antibody was add and then incubated for 45 minutes up to 1 hour at $37^{\circ} \mathrm{C}$. Samples were then reacted with conjugate Fab IgG labeled with FITC (fluorescence isothiocyanat). Samples were washed with PBS and then being added wit $10 \mu \mathrm{l}$ oil immersion over the cell then covered with a cover glass. Samples were viewed with fluorescence microscopy after 1 to 3 hours with a green filter (Rantam et al. 2014).

\section{Osteogenic differentiation and administration of melatonin}

Once the cells reached 2 pieces of petridish with $10 \mathrm{~cm}$ in diameter (5x passage), cells were transferred into 24 well plates and were given the osteogenic medium which consisted of DMEM-HG, 10\% FCS, $100 \mathrm{~nm}$ dexamethasone, $0.1 \mu \mathrm{M}$ ascorbic acid and $10 \mathrm{~nm}$ betaglycerophosphate (Lindenmair 2012). After the cells attached to the wall plate, the cell was provided with melatonin (Ebcam, China) in accordance with the treatment group. Each wells were chosen randomly then to be divided into four groups, namely $\mathrm{K} 1$ (melatonin 0 $\mathrm{nM}$ ), K2 (melatonin $25 \mathrm{~nm}$ ), K3 (melatonin $50 \mathrm{~nm}$ ) and $\mathrm{K} 4$ (melatonin $100 \mathrm{~nm}$ ). This study was conducted for up to 21 days to examine the results of differentiation of osteoblast activity of BM-MSCs.

\section{Confirmation of the activity of osteoblasts}

Osteoblast activity can be seen in the levels of ALP and osteocalcin as well as staining with alizarin Red. Osteoblast activity in this study shows the success of differentiation and maturation of BM-MSCs into osteoblasts. 


\section{Alizarin red staining}

Acidity level of the cells on the plate were first being checked, because the $\mathrm{pH}$ of the cells must be in the range of 4,1- 4.3. Cells were being washed twice with PBS, then being dried. Cells were fixed with $3 \%$ formalin buffer (Sigma, USA), and incubated at room temperature for 15-30 minutes and then provided with Alizarin red (Sigma, USA), and allowed to stand for 1 hour.

\section{ALP levels}

Cells in 24 well plate being lysed with radio immune precipitation assay (RIPA) lysis buffer $200 \mathrm{~mL}$ in each well. Cells were then incubated for 5-10 minutes, for then underwent homogenization with suction and spray techniques. ALP was examined using ELISA technique (Elabscience, China). Principles used in ALP examination with this method were to add ALP-specific antibodies in microELISA plate, standard or a sample for as many as $100 \mathrm{~mL}$. Biotinylated detection antibody and HRP conjugated were then being provided. The substrate solution was being added and containing only ALP, Biotinylated detection antibody and HRP conjugated will appear in blue. In this technique, the reaction of enzyme and substrate will be terminated by adding sulphuric acid solution and the color will change to yellow. Then the colors were detected and Optical Density (OD) was measured with a spectrophotometer (ELISA reader) at a wavelength of $450 \mathrm{~nm} \pm 2 \mathrm{~nm}$. OD value is proportional to the concentration of ALP. ALP concentration of the sample can be assessed by comparing the OD of samples on the standard curve (Elabscience 2014a).

\section{Osteocalcin levels}

Medium collected from the culture of BM-MSCs, were then being examined to obtain the levels of osteocalcin using ELISA technique (Elabscience, China). The principle used in osteocalcinexamination with this method is to add osteocalcin-specific antibody on microELISA plate, standard or a sample for as many as $100 \mathrm{~mL}$. Then, Biotinylated detection antibody and Avidin-Horseradish Peroxidase (HRP) were being conjugated. The substrate solution was added and only tat of Osteocalcin, Biotinylated detection antibody and Avidin-Horseradish Peroxidase (HRP) conjugated will appear in blue. The reaction of the enzyme and substrate will be terminated by adding Sulphuric acid solution and the color will change to yellow. Then the colors were detected and Optical Density (OD) was measured with a spectrophotometer (ELISA reader) at a wavelength of $450 \mathrm{~nm} \pm 2 \mathrm{~nm}$. OD value is proportional to the concentration of osteocalcin. Osteocalcin concentration in samples can be assessed by comparing the OD of samples on the standard curve (Elabscience2014b).

\section{Statistic analysis}

The results of this study were presented with average value \pm standard deviation (SD), normality of data were checked using shapirowilk test and homogeneity were checked using levene test. When the data was considered as normal, then the statistic difference were analyzed using analysis of variance (ANOVA) and when the result were $\mathrm{P}<0.05$ then they would be followed by post Hoc test. However, when the normality and homogeneity of cells were abnormal then it would be followed by alternative test using the kruskal wallis.

\section{RESULTS}

\section{BM-MSCs Characterization}

Characterization of Rat BM-MSCs, was done through immunocytochemistry examination labeled with green fluorescence (FITC). The principles of such examinations were using cells, primary antibodies and secondary antibodies labeled with FITC (fluorescence isothiocyanat) so that the positive cells will appear as green-fluorescent. In this study, cells labeled as CD105+ appeared strong green-fluorescent, whereas cells labeled as CD45- appeared weak green-fluorescent.

\section{BM-MSCs culture}

The culture of rat BM-MSCs were performed when growing the isolated mononuclear cells from femur bone marrow until passage 5 in $\alpha$-MEM medium grower. By the time the mononuclear cells were first isolated, they could be observed as floating and roundin-shape, after the initial passage, the cells change the size while still relatively small in size, spindle-shaped, and at the end of the passage, cells will turn into big and flat. The culture of rat BM-MSCs was then continued using osteogenic medium and provided with melatonin in dosage of $0 \mathrm{nM}, 25 \mathrm{nM}, 50 \mathrm{nM}$ and $100 \mathrm{nM}$. The cells were harvested after 21 days. The result showed that the morphology of the cells has begun to change, and seems to have differentiated because the cells began to grow wider and somewhat columnar (Fig. 1).

\section{Alizarin Red staining}

Alizarin red examination performed on day 15 to assess the mineralization of extracellular rat BM-MSCs differ- 
entiated into active osteoblasts. Spotting the red color in the cell, showed there is deposition of calcium in the mineralization process.
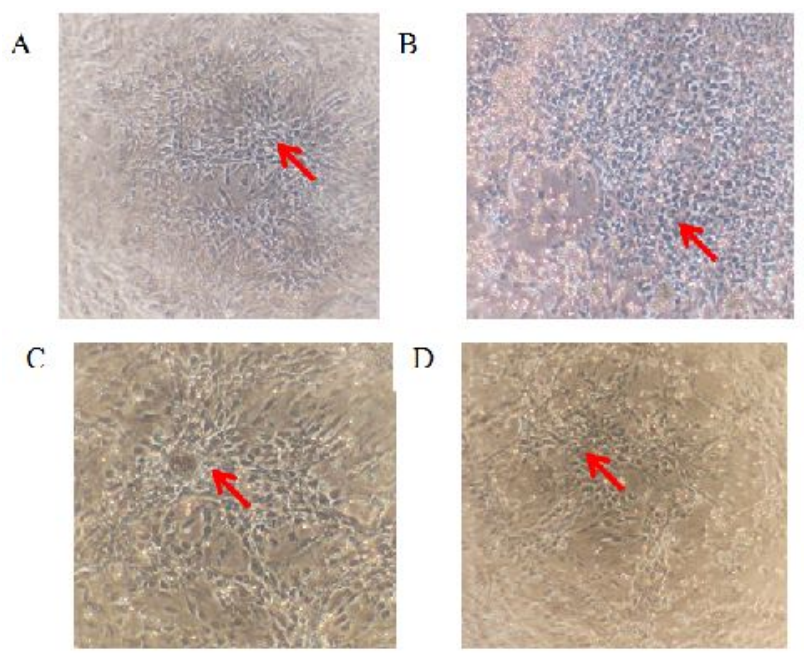

Fig. 1. The morphology of rat BM-MSCs after 21 days melatonin administration by inverted microscope 10 x. A. Control; B. Melatonin $25 \mathrm{nM}$; C. Melatonin $50 \mathrm{nM}$; D. Melatonin $100 \mathrm{nM}$
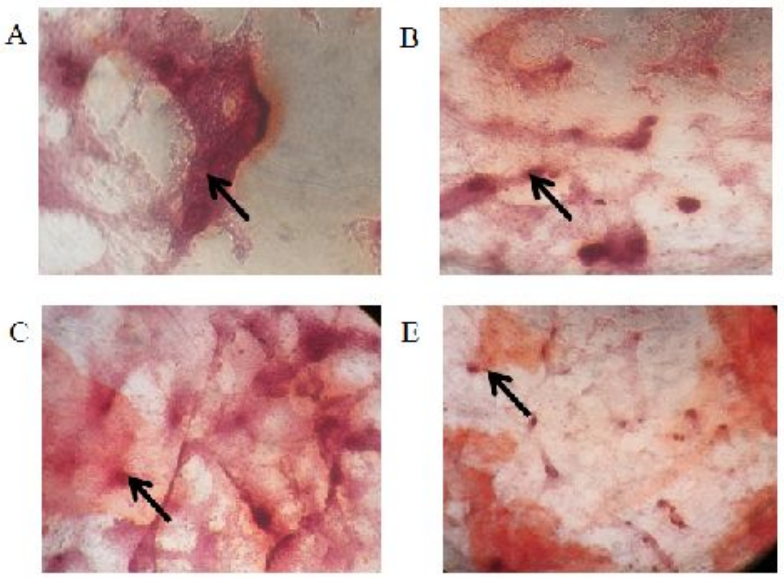

Fig. 2. Alizarin Red staining in BM-MSCs. A. K0 (Control); B. K1 (Melatonin $25 \mathrm{nM}$ ); C. K2 (Melatonin $50 \mathrm{nM}$ ); C. K3 (Melatonin $100 \mathrm{nM}$ )

\section{ALP levels}

This study was conducted to examine the elevation of ALP levels in cultured rat BM-MSCs in osteogenic medium exposed in different physiological dosage of melatonin; $25 \mathrm{nM}, 50 \mathrm{~nm}$, and $100 \mathrm{nM}$. ALP levels data obtained with ELISA examination from cells that have been lysed with RIPA lysis buffer in the control and treatment groups, were presented in mean values and SD.

Table 1. Mean values and SD of ALP Levels

\begin{tabular}{lccc}
\hline Treatment groups & $\begin{array}{c}\text { Sampel } \\
(\mathrm{N})\end{array}$ & $\begin{array}{c}\text { Meanof } \\
\text { ALP level } \\
(\mathrm{ng} / \mathrm{ml})\end{array}$ & $\mathrm{SD}$ \\
\hline Control $\left(\mathrm{K}_{0}\right)$ & 6 & 6.025 & 0.190 \\
Melatonin $25 \mathrm{nM}\left(\mathrm{K}_{1}\right)$ & 6 & 5.253 & 0.381 \\
Melatonin 50nM(K $\left.\mathrm{K}_{2}\right)$ & 6 & 5.326 & 0.224 \\
Melatonin 100nM $\left(\mathrm{K}_{3}\right)$ & 6 & 5.169 & 0.192 \\
\hline
\end{tabular}

ALP levels were obtained and then being examined for normality using Shapiro Wilk Test. Normality test showed that the distribution in all treatment groups were normal because of $p>0.05$. Test was followed by Levene Test to determine the variance of ALP levels. The data were known to have same variance (homogen-eous) because the $\mathrm{p}=0134(\mathrm{p}>0.05)$. The data were in normal distribution and variance, for then the analysis of difference in levels of ALP between groups was performed using ANOVA. The results showed that there was no significant differences between the ALP levels in at least two treatment groups, because the value of $p$ $>0.05$.

\section{Osteocalcin levels}

This study was conducted to examine the increase in osteocalcin levels in cultured rat BM-MSCs in osteogenic medium exposed with different physiological dosage of melatonin; $25 \mathrm{nM}, 50 \mathrm{~nm}$, and $100 \mathrm{nM}$. Osteocalcin levels obtained by ELISA examination from the cultured medium in both control and treatment groups were presented in mean values and SD.

Table 2. Mean values and SD of osteocalcin levels

\begin{tabular}{lccc}
\hline Treatment group & $\begin{array}{c}\text { Sampel } \\
(\mathrm{N})\end{array}$ & $\begin{array}{c}\text { Mean of } \\
\text { Osteocalcin } \\
\text { level }(\mathrm{ng} / \mathrm{ml})\end{array}$ & SD \\
\hline Control $\left(\mathrm{K}_{0}\right)$ & 6 & 1.123 & 0.216 \\
Melatonin 25nM $\left(\mathrm{K}_{1}\right)$ & 6 & 5.656 & 0.366 \\
Melatonin 50nM $\left(\mathrm{K}_{2}\right)$ & 6 & 8.567 & 1.222 \\
Melatonin 100nM $\left(\mathrm{K}_{3}\right)$ & 6 & 5.635 & 0.842 \\
\hline
\end{tabular}

Osteocalcin levels obtained were then tested for normality using Shapiro Wilk Test because the samples used were $\leq 50$. Test of normality showed that the distribution of the treatment group $\mathrm{K} 1$ was normal because $p>0.05$, while in the other three groups were not normal for $p<0.05$. This test was followed by Levene Test to determine the variance of osteocalcin levels data. Data had been known to have different 
variances (not homogenous) in groups of $\mathrm{K} 0, \mathrm{~K} 2, \mathrm{~K} 3$ because $\mathrm{p}<0.050$, and data on group $\mathrm{K} 1$ were homogeneous. Analysis in difference in osteocalcin levels among groups conducted withKruskal-Wallis Test. Kruskal-Wallis Test results showed the value of $\mathrm{P}$ $<0.05$ so that it can be concluded that there were at least significant difference in osteocalcin levels between the two treatment groups. Osteocalcin data analysis done with the Mann-Whitney Test conducted to determine which groups that were different. The result showed that there was no difference in osteocalcin levels between groups $\mathrm{K} 1$ and $\mathrm{K} 3$, and $\mathrm{K} 2$ and $\mathrm{K} 3$ because of $\mathrm{p}>0.05$. However, there were differences in osteocalcin levels between groups of $\mathrm{K} 0$ and $\mathrm{K} 1, \mathrm{~K} 0$ and $\mathrm{K} 2, \mathrm{~K} 0$ and $\mathrm{K} 3$, and $\mathrm{K} 1$ and $\mathrm{K} 2$.

\section{DISCUSSION}

Rat BM-MSCs are stem cells isolated from rat's bone marrow and can be cultured through several passages. BM-MSCs possess properties that make the growth faster compared to the adipose-derived ones. In this process, the necessary thing is conformity between the process of isolation of the femur of the rats with sample preparation in the laboratory, so that the isolated samples can be handled faster and the percentage of living cells can reach up to $70 \%$. The development of mononuclear cell into BM-MSCs was influenced by several factors, including the medium used for grower, osteogenic medium, and laboratory conditions. These three factors are needed to maintain the environmental conditions of cells such as in vivo conditions necessary for live BM-MSCs, proliferation, and ostogenic differentiation (Eijkenet al. 2005; Lindenmairet al. 2012; Rantamet al. 2014; Wang et al. 2015).

Quality osteoblast activity is characterized by the success of osteoblast cells to produce proteins - important proteins in the process of osteogenesis. The process of osteogenesis consists of a process of differentiation of BM-MSCs into active osteoblasts and active osteoblast maturation into osteocytes. BM-MSCs differentiation into active osteoblasts is divided into three phases. The first phase is a phase of increasing quantity of BM-MSCs. The second phase is early differentiation phase marked by the BM-MSCs turned into preosteoblasts which produces one of bone forming factors: Alkaline phosphatase (ALP) (Birmingham 2012). The third phase is the final phase of differentiation and at the beginning of the maturation process, characterized by changes of preosteoblasts into osteoblasts that have been able to secrete proteins important for mineralization such as osteocalcin (Golub \& Battaglia 2007).
ALP is a precipitate enzyme needed for bone mineralization process. Expression of ALP is regulated by transduction signal extracellular signal- regulated kinase(ERK) 1/2, runt-related transcription factor 2 (RUNX-2), osterix and wingless-type MMTV integration site family (WNT) signaling (Golub \& Battaglia 2007). The purpose of this study was to explain the elevated levels of ALP on cultured Rat BM-MSCs in osteogenic medium exposed with physiological dosage of melatonin. The results indicated that by using the ANOVA there were no significant differences in the levels of ALP between each treatment groups: control group and the groups provided with melatonin in dosage of $25 \mathrm{nM}, 50 \mathrm{nM}$ and $100 \mathrm{nM}$ (p>0.05). The mean levels of ALP in the control group was $6025 \pm 0190 \mathrm{ng} /$ $\mathrm{ml}$, was known to be higher compared to the treatment group provided with melatonin in dosage of $25 \mathrm{nM}, 50$ $\mathrm{nM}$ and $100 \mathrm{nM}$.

The results of this study indicated different result from the one conducted by Radio et al. (2006), Zaminy et al. (2008) and Sethi et al. (2010). These studies showed that the levels of ALP produced by osteoblast cells in the group provided with melatonin were higher than the group that were not provided with melatonin. Sethi et al. (2010) used Human BM-MSCs as the samples while Zaminy et al. (2008) used Rat BM-MSCs in his study. The study explained that the mineralization process, which is part of the process of BM-MSCs differentiation into osteoblasts, were on days 14 - 28 with continuous administration of melatonin. ALP activity is also known to increase along with the process of differentiation (Roth et al. 1999; Satomura et al. 2007;Zaminy et al. 2008).

The results of this study differ from previous studies because of several factors. Difference in BM-MSCs cells usedwas one of the important factors that could affect the differences in levels of ALP. Each animal has different stem properties. Adaptation to become activated, proliferated, and differentiated into progenitor cells in the microenvironment were also vary (Rantam et al. 2014). BM-MSCs isolated from humans have different ability to grow compared with that the BM-MSCs obtained from the rats. According Scuteri et al. (2014), osteogenic differentiation of rats' BM-MSCs can be identified quantitatively by staining after day 14 , and human BM-MSCs can only be identified after day 28 . However, it is not always clear, because it depends highly on the nature and quality of BM-MSCs.

The difference in time examination may also be the cause of differences in levels of ALP. Research conducted by Radio et al. (2006), Zaminy et al. (2008) and Sethi et al. (2010) carried out in serial manner while this study was only done once at day 21 . Birminghamet 
al. (2012) reported that the ALP expression was highest on days 5-14 while examination of ALP levels in this study was performed on day 21 . At the time of inspection, the ALP levels may have decreased because after the initial peak phase, ALP levels will decrease slowly (Birmingham et al. 2012). Melatonin is thought to be able to increase the differentiation of rat BM-MSCs. Besides faster, the highest levels of ALP had occurred on day 14 or earlier. Thus, on day 21 , rat BM-MSCs have been in the late phase of synthesis and extracellular matrix mineralization, and the cellular ALP levels have decreased (Neve et al. 2010). This assumption is consistent with the results of the study showing that levels of ALP in groups provided with melatonin were lower compared to the control group. The groups provided with melatonin will undergo differentiation faster than the control ones, so that the ALP would be faster reaching the peak level and will more quickly decreasing after passing the peak. This is reinforced by Alizarin Red examination, which, showed that at day 15 there had been calcium deposition which is a marker of matrix mineralization. Matrix mineralization occurs after the initial phase in which the cell differentiation of BM-MSCs have been turned into preosteoblasts and preosteoblasts have turned into active osteoblasts.

Good regulatory system cells can also be used to explain the results. When cells approach the final phase of differentiation, the differentiation marker that appears is a specific marker of that phase and followed by a decline of the previous marker. The cells inthis study have been at the end of synthesis and mineralization of extracellular matrix phase that that osterix system will have a major role. If the system work, then the protein mineralization that are most widely produced as osteocalcin, osteopontin, osteonectin and normally, ALP and other proteins in initial phase of differentiation will decrease in production. This shows that melatonin is not only capable of inducing osteoblast activity but is also regulating these activities so that maturation towards osteocytes can be attained (Golub\&Battaglia 2007).

Osteocalcin, also known as bone gamma-carboxyglutamic acid (Gla) proteins (BGP) is a non-collagen protein in the bone matrix, and is regulated by transduction signals ERK1/2, RUNX-2, systems osterix, and WNT signal, interconnected with each other (Golub \& Battaglia2007). Osteocalcin levels has the highest expression in the last phase of differentiation on the day 14-28 followed by deposition of calcium and phosphate (Birmingham et al. 2012).

The purpose of this study was to explain the elevation of osteocalcin levels in cultured rat BM-MSCs using osteogenic medium exposed with different dosage of melatonin; $25 \mathrm{nM}, 50 \mathrm{nM}$ and $100 \mathrm{nM}$. These results indicated that there were significant differences in Osteocalcin levels between the control group and the groups provided with melatonin in dosage of $25 \mathrm{nM}, 50$ $\mathrm{nM}$ and $100 \mathrm{nM}$, with $\mathrm{p}$ value of $<0.05$. It also shows that melatonin can improve rat BM-MSCs differentiation into osteoblasts which is alo able to secrete active osteocalcin. Among the three treatments, administration of melatonin at a dose of $50 \mathrm{nM}$ can provide Osteocalcin levels with the highest mean, ie $8567 \pm$ $1222 \mathrm{ng} / \mathrm{ml}$, although only significantly different with dosage of $25 \mathrm{nM}$. It shows that compared to the administration of melatonin in dosages of $25 \mathrm{nM}$ and $100 \mathrm{nM}, 50 \mathrm{nM}$ dosage administration of melatonin is the most optimal in increasing differentiation of rat BMMSCs.

The results were consistent with previous studies that reported by Zaminy et al. (2008) that melatonin in physiological dosage can improve the rat BM-MSCs differentiation into actively osteoblasts marked by an increase in osteocalcin mRNA. Melatonin in dosage of $50 \mathrm{nM}$ binds to melatonin receptors in the BM-MSCs then increases the activity of WNT and ERK $1 / 2$ and suppresses adipogenic transcription factor CCAAT enhancer binding protein $\alpha(\mathrm{C} / \mathrm{EBP} \alpha)$ and peroxisome proliferator-activated receptor $\gamma(\operatorname{PPAR} \gamma)$ and induces Runt-related transcription factor (RUNX-2), distal-less homeobox 5 (Dlx5) and Osterix (OSX) which would trigger rat BM-MSCs differentiation into active osteoblasts which secretes several non-collagen protein, such as osteocalcin (Radio et al. 2006; Rucci 2008). RUNX-2 increases the transcription of osteocalcin because it can bind directly the specific enhancer regions of genesencoding osteocalcin and activate other osteoblastic genes such as BMP-2. The results of this study are were consistent with studies conducted by Radio et al. (2006) who found a dosage of $50 \mathrm{nM}$ is the optimal dose in increasing differentiation of BM-MSCs into active osteoblasts.

Melatonin is hormone that is naturally produced by pineal gland, located in the center of the brain and has a wide range of important biological functions in body.Melatonin can regulate circadian rhythms, sleep and wake cycles, the immune system, as an antioxidant and tissue homeostasis redox reaction. Melatonin also plays an important role in bone health through its role in regulating the mechanism of formation and bone resorption in bone remodeling (Luchetti et al. 2014; Maria \&Enderby 2014).

These results indicated that an elevation of osteoblast activity in the rat BM-MSCs in osteogenic medium exposed with melatonin through elevation ofosteocalcin levels in treatment groups, but did not affects the levels 
ALP. The increase in osteoblast activity can occur if BM-MSCs are well differentiated. BM-MSCs differentiated into osteoblast in several phases and is characterized by a change of MSCs into osteoproge-nitor, preosteoblasts, early osteoblasts, late osteoblasts, and perfect differentiated osteoblasts. Early stage of these changes, there are important markers that can be used. ALP is a marker that indicates that preosteobast transform into early osteoblast and the levels will remain high until the cell turns into late osteoblasts. When the cells are in late osteoblasts phase, it will transform into and osteocytes, ALP levels will decrease and be replaced by increased osteocalcin. Perfectly- differentiated osteoblasts will produce osteopontin as a marker. Therefore, an increase in osteocalcin in the study is sufficient to show that the BM-MSCs differen-tiated into late osteoblasts (Nakamura et al. 2009; Beedermanet al. 2013).

The elevation of osteoblast activity is associated with bone health. Low osteoblast activity is will cause an imbalance in bone formation and resorption so that the bone health will suffer. Osteoporosis is a condition that indicates a low activity of osteoblasts where the mechanism of bone resorption occurs higher than the formation. Patients with osteoporosis have low bone mass and strength, deterioration and disruption of bone architecture occur, as well as an increased risk of fractures. Therefore, the osteoporosis disease needs an increase in osteoblast activity which increase the formation and decreases bone resorption.

Osteoporosis occurs due to various factors, one of them is the aging factor. Aging causes a decrease in the reproductive system so that the level of estrogen and progesterone decreases. The decline led to an increase of glucocorticoid hormones that inhibit the synthesis of collagen in the body, including the collagen needed for bone formation. In addition, aging also causes a decrease in plasma melatonin levels significantly in evenings. The decline is parallel with the progress of bone deterioration in osteoporosis patients. Therefore the role of melatonin decline in the pathophysiology of osteoporosis and the ability of melatonin to increase the activity of osteoblasts to produce the protein for bone formation, making melatonin as a good therapeutic target to be considered for osteoporosis (Zaminy et al. 2008; Barcello et al. 2010 ).

Anti-osteoporosis therapies that are currently used are biphosphonat, estrogen and calcitonin and tend only to inhibit osteoclast resorption process to prevent the destruction of large bones. However, this therapy is not suitable for use in individuals who suffer from severe osteoporosis. Drugs used to stimulate bone formation by osteoblasts (teriparatide) are expensive and have impor- tant side effects. Therefore, melatonin can be considered to be a new therapy that can improve and manage both the process of formation and resorption of bone (Barchelo et al. 2010).

Currently, the treatment for osteoporosis has begun to use stem cells as an agent. MSCs are known as the leading potential candidate with roles in the process of growth and regeneration. Isolated MSCs from the bone marrow can be cultured and propagated in vitro and can be infused back to osteoporosis patient. However, MSCs reported to require selective sera lots and supplements for growth factor for the development of culture. According to Gasser (2003), MSCs for the treatment of osteoporosis requires an osteogenic differentiation agent to be able to differentiate into osteoblasts. Pino et al. (2012) reported that in patients with osteoporosis, MSCs tend to differentiate into adipose and not become osteoblasts because of interference on the intrinsic properties and the microenvironment of MSCs. Thus, MSCs therapy for osteoporosis patients brings new hope and melatonin can be considered as a supplement growth factors to obtain the maximum expansion of MSCs and can be used to manage the MSCs to be able to differentiate into osteogenic pathway (Gasser 2003; Zaminyet al. 2008; Pino et al. 2012).

\section{CONCLUSION}

There were an elevation of osteoblast activity in rat BM-MSCs in osteogenic medium by physiological doses of melatonin administration characterized by the elevation of osteocalcin level.

\section{REFERENCES}

Barcelo EJS, Mediavilla MD, Tan DX, Relter RJ (2010). Scientific Basis for the Potential Use of Melatonin in Bone Diseases: Osteoporosis and Adolescent Idiopathic Scoliosis. Journal of Osteoporosis, 1-10

Beederman M, Lamplot JD, Nan G, Wang J, Liu X, Yin L, Li R, Shui W, Zhang H, Kim SH, Zhang JZ, Kong Y, Denduluri S, Rogers MR, Pratt A, Haydon RC, Luu HH, Angeles J, Shi LL, He TC (2013). BMP signaling in mesenchymal stem cell differentiation and bone formation.J. Biomedical Science and Engineering 6, 32-52.

Eijkenn M, Koedam M, Driel V, Buurman CJ, Pols HAP, LeeuwenJPTM. 2006.The essential role of glucocorticoids for proper human osteoblast differentiation and matrix mineralization. Molecular and Cellular Endocrinology34, 1-7. 
Elabscience (a) (2014). Rat ALP (Alkaline Phosphatase) ELISA Kit 5 th Edition. ElabscienceBiothechnology Co, Ltd. www.elabscience.com

Elabscience (b) (2014). Rat OC/BGP (Osteocalcin) ELISA Kit 5 th Edition. ElabscienceBiothechnology Co, Ltd. www.elabscience.com.

Gasser, JA (2003). Stem Cells in the Treatment of Osteoporosis.European Cells and Materials 6, 1-21.

GolubEE, Battaglia KB (2007). The role of alkaline phosphatase in mineralization.CurrOpinOrthop,444 448.

Lindenmair A, HatlapatkaT, KollwigG, Hennerbichler S, GabrielC, WolbankS, Redi H, KasperC (2012). Mesenchymal Stem or Stromal Cells from Amnion andUmbilical Cord Tissue and Their Potential for Clinical Applications. Cells, 1, 1061-1088.

Luchetti F, Canonico B, Bartolini D, Arcangeletti M, ciffolilliS, MurdoloG, PiroddiM, PapaS, Reiter RJ, Galli, F (2014). Melatonin regulates mesenchymal stem cell differentiation: a Review. J.Pineal Res 56,382-397.

Maria S, Enderby PAW (2014). Melatonin effects on bone: potential use for the prevention and treatment for osteopenia, osteoporosis, and periodontal disease and for use in bone-grafting procedures. J.Pineal Res $56,115-125$.

Nakamura A, Dohi Y, Akahane M, Ohqushi H, Nakajima H, Funaoka H, Takakura Y (2009). Osteocalcin secretion as an early marker of in vitro osteogenic differentiation of rat mesenchymal stem cells.Tissue Eng Part C Methods 15, 2, 169-180.

National Osteoporosis Foundation (2014).Clinician's Guide To Prevention And Treatment Of Osteoporosis. National Osteoporosis Foundation, 1-55.

Neve A, CorradoA, PaoloF, Cantatore, P (2010). Osteoblast Physiology in normal and pathological Condition. Cell Tissue Res, 1-14.

Pino AM, Rosen CJ, Rodriguez JP (2012). In Osteoporosis, differentiation of mesenchymal stem cells (MSCs) improves bone marrow adipogenesis. Biol Res 45, 279-287.

Radio NM.; Doctor JS, Enderby PAW (2006). Melatonin enhances alkaline phosphatase activity in differentiating human adult mesenchymal stem cells grown in osteogenic medium via MT2 melatonin receptors and the MEK/ERK1/2 signaling cascade. J. Pineal Res40, 332-342.

RantamFA, Ferdiansyah,danPurwati (2014).Stem Cell; Mesenchymal, Hematopoetikdan Model Aplikasi Edisi Kedua. Surabaya: Airlangga University Press, 23-40.

Riggs BL, Melton LJ (1995). 3rd The Worldwide Problem Of Osteoporosis: Insights Afforded By Epidemiology Bone 17, 505-511.

Roth JA, Kim BG, Lin WL, Cho M. 1999. Melatonin Promotes Osteoblast Differentiation And Bone Formation. The Journal Of Biological Chemistry 274, 31, 2041- 2247.

Rucci, N (2009). Molecular biologyof bone remodeling.Clinical Case in Mineral and Bone Metabolisme, $5,1,49-56$.

SatomuraK, Tobiume S, Tokuyama R, Yamasaki Y, Kudoh K, MaedaE, NagayamaM (2007). Melatonin at pharmacological doses enhances human osteoblastic differentiation in vitro and promotes mouse cortical bone formation in vivo. J. Pineal Res, 1-10.

ScuteriA, Donzelli, E, FoudahD, CaldaraC, RedondoJ, AmicoGD, TrediciG, Miloso M (2014). Mesengenic Differentiation: Comparison of Human and Rat Bone Marrow Mesenchymal Stem Cells. International Journal of Stem Cells 7, 1-8.

Sethi S, Radio NM, Kotlarczyk MP, Chen CT, WeiYH, Jockers R, dan Enderby PAW (2010).Determination of the minimal melatonin exposure required toinduce osteoblast differentiation from human mesenchyma stem cells and these effects on downstream signaling pathways. J.Pineal Res49, 222-238.

Wang Y, Zhu G, Li N, Song J, Wang L, SI X, 2015. Small molecules and their controlled release that induced the osteogenic/chondrogenic commitment os stem cells. Biotechnology advances 5, 1-15.

ZaminyA, Kashani IR, BarbarestaniM, HedayatpourA, MahmoudiR, Nejad AF (2008). Osteogenic Differentiation of Rat Mesenchymal Stem Cells from Adipose Tissue in Comparison with Bone Marrow Mesenchymal Stem Cells: Melatonin As a Differentiation Factor. Iranian Biomedical Journal 12, 3, 133 -141. 